SYMPOSIUM ON DRUGS

\title{
Prescribing cannabis: freedom, autonomy, and values
}

M Hayry

J Med Ethics 2004;30:333-336. doi: 10.1136/jme.2002.001347

In many Western jurisdictions cannabis, unlike most other psychoactive drugs, cannot be prescribed to patients even in cases where medical professionals believe that it would ease the patient's pain or anxiety. The reasons for this prohibition are mostly ideological, although medical and moral arguments have been formulated to support it. In this paper, it is argued that freedom, properly understood, provides a sound ethical reason to allow the use of cannabis in medicine. Scientific facts, appeals to harm and autonomy, and considerations of symbolic value cannot consistently justify prohibitions.

WHAT ARE THE QUESTIONS?

A hypothetical case

Suppose that I suffer considerably. My suffering can manifest itself as localised physical pain, general queasiness, or involuntary convulsions. Suppose, further, that I have, by consulting medical literature, become convinced that cannabis is the solution to my problems-that smoking marijuana or ingesting pills containing cannabinoids would alleviate my suffering without causing disproportionate side effects. Should $\mathrm{I}$, in this case, be free to use cannabis to make myself feel better? And, above all, what would be the implications of this freedom to medical professionals?

\section{Four steps to freedom}

I will answer these questions by proceeding in four stages. I will first consider briefly the scientific facts of the case, and reject the view that the prohibition of cannabis can be based on medical expertise. My second step is to define freedom and its normative foundation, and to sketch the practical guidelines that respect for freedom would entail for healthcare professionals. The third task is to clarify the distinction between freedom and autonomy, which is often blurred in ethical and legal discussions. The fourth and final step is to assess, and to reject, the main moral and political arguments against the use of cannabis in medicine.

Correspondence to: $M$ Hayry, Centre for Professional Ethics, University of Central Lancashire, UK; mhayry@uclan.ac.uk

Received 13 August 2002 In revised form 23 September 2003 Accepted for publication 20 October 2003 peripheral nervous systems, and that cannabinoids are analgesic and reduce signs of neuropathic pain in animals. ${ }^{1-7}$ There is also some evidence that they can reduce pain, nausea, and spasms in humans. ${ }^{6-9}$ Against these findings, it has been argued that the medical benefits of cannabis are overshadowed by its harmful side effects, and that due to other developments in pain management, there is no real need for its use as an analgesic. ${ }^{67}$ As it is illegal and unpopular to conduct studies on the effects of marijuana and related products in most Western countries, it is unlikely that decisive scientific clarity will be reached in the near future.

\section{Professional disagreement}

Professional opinion, however, seems to favour a liberal approach. In a survey conducted in 1997, the majority of British doctors wanted cannabis prescriptions to be allowed. ${ }^{10}$ An earlier study showed that in the late 1980s the majority of the members of the Washington Medical Association would have preferred, against the current state law, the controlled medical availability of marijuana. ${ }^{11}$ In the early 1990s, 44\% of oncologists surveyed had already recommended the illegal use of marijuana to at least one patient. ${ }^{12}$ And in 1997, the editor of the influential New England Journal of Medicine argued against the prohibition in an editorial. ${ }^{13}$

\section{No consistent medical argument}

Arguments against the use of cannabis cannot be supported by scientific facts. The use of marijuana can have drastic side effects, but nobody seems to deny that it can also benefit some individuals considerably. If I am one of those individuals, and willing to risk the side effects, then what could reasonably be said against selling or prescribing cannabis to me? As the divided professional opinion indicates, there is no satisfactory scientific or medical answer to this question.

\section{FREEDOM AND ITS IMPLICATIONS}

The main arguments for allowing cannabis use, sale, and prescriptions stem from the ideas of freedom and autonomy. It is widely assumed in healthcare ethics that the freedom of individuals is best protected by paying heed to the principle of self determination, or autonomy. ${ }^{14}$ The two concepts have also been more or less equated in the context of drug prohibitions. ${ }^{15}{ }^{16}$ But this is not necessarily a valid connection. Depending on the interpretations chosen, respect for autonomy can lead to restrictions of freedom. The best way to defend my entitlement and access to the medication I want is to forget autonomy and to proceed from an early liberal "thin" concept of freedom, or liberty. ${ }^{17}{ }^{18}$
There is evidence that human beings have receptors for cannabinoids in the central and 


\section{What is freedom?}

In what follows, I will take freedom to mean the nonrestriction of options. In other words, an individual is free to the degree that her options remain open to her. And, conversely, an individual is unfree to the extent that her options are ruled out by clearly definable constraints, which can be external or internal, positive or negative. ${ }^{19} 20$

Within this definition, nobody is perfectly free: because of physical limitations, human beings cannot fly like eagles, swim like sharks, or jump like tigers; because of economic constraints, most people cannot afford to buy a new car every month, and some people cannot even afford to buy food every day; because of gaps in education, many people cannot make informed decisions regarding their own lives, and because of social and cultural restrictions, many people cannot express their true opinions without fear of untoward consequences.

\section{Why should freedom be respected?}

The basis for respecting freedom as the non-restriction of options can be found in the seventeenth century liberal doctrine usually attributed to John Locke. ${ }^{21}$ According to this doctrine, individuals have rights. The most important of these are the right to life, the right to health, the right to liberty, the right to bodily integrity, the right to private property, and the right to punish those who violate other people's rights.

These rights are, essentially, entitlements to non-interference. Other people should not actively attempt to end our lives, corrupt our health, steal our property, or curtail our freedom of choice. If they do, or attempt to do, any of these things, they partly lose their original entitlements, and we have the right to punish them, or prevent them by threats of punishment.

The rights individuals possess were, in Locke's original model, based on the idea that people do not in the end belong to themselves, but to God. We have a strict duty not to interfere with the lives, health, and liberty of other individuals, because they should be left free to manage their God given lives for themselves. They should do this in the best way they can, in the light of their reason and understanding, but even if they do not, we cannot legitimately interfere, given that they do not violate the rights of others.

This defense of freedom as the non-restriction of options does not necessarily depend upon any particular view of God, religion, or theology. It can be taken simply to mean that our individuality, as expressed by our own choices, is an extremely valuable thing, and that attempts by others to mess with it cannot add anything to its value. To use a metaphor popular in bioethical debates, we could say that others are trying to "play God" if they insist that their claims and beliefs should override our choices. ${ }^{22} 23$

\section{How could freedom be professionally respected?}

It seems clear to me that respect for freedom is not compatible with excessive regulations on the sale and use of cannabis in non-medical contexts. The use of possibly addictive substances does foreclose some future options, but so do many other practices and choices which are widely accepted in the name of liberty. Decisions to have children and to take a mortgage spring to mind. If competent individuals want to use cannabis, they cannot be stopped by appeals to their freedom. The question is, does the medical context change the situation?

Healthcare professionals can respect and promote the freedom of their patients in two ways. They can try not to eliminate any options open to the patients before the professional contact. And they can try to remove physical, economic, educational, and social constraints by their professional efforts and by civic participation. But what about prescribing cannabis to alleviate pain or anxiety, where the patient has expressed a clear preference in its favour?
Legislation obviously plays an important role in what health professionals can and cannot do. If the use of marijuana for medical purposes is legally allowed, then health professionals would, by denying the request, rule out an existing option, and thereby explicitly restrict their patient's freedom. If, on the other hand, the use of cannabis is prohibited, the option is not in the same way open to patients before the consultation.

It can be argued that in the latter case the freedom of the patient making the request is not actively restricted by the professionals. But as the option remains closed, the freedom of the individual is not maximally promoted, either. It could, namely, be further enhanced by attempts to legalise marijuana.

This means that, whatever the legal situation, respect for the freedom of the individual would imply that requests like this should be granted, either by health professionals or by society as a whole.

\section{AUTONOMY AS A FREEDOM RESTRICTING PRINCIPLE}

Autonomy can be inimical to freedom, although this is not necessarily the case. According to a liberal interpretation, based on the work of the nineteenth century thinker John Stuart Mill, individual liberty and personal self determination cannot be separated. ${ }^{24} 25$ But many ethicists and lawyers prefer another reading, in which autonomy is subjected to particular notions of reason and contrasted with freedom as the non-restriction of options. ${ }^{26-28}$

\section{What is autonomy?}

The definition of autonomy usually employed in healthcare ethics can be traced back to the eighteenth century, to the philosophy of Immanuel Kant. ${ }^{29-31}$ He held the view that autonomy means personal self determination in the light of universal reason. People can, according to his doctrine, be "truly free" only in the realm of rationality: if they yield to their desires, attitudes, or emotions, they reject their autonomy and their "true freedom". As desires, attitudes, and emotions are a constant factor in our lives, Kant believed that people cannot be perfectly autonomous, but he argued that we have a moral duty to try to achieve this impossible goal.

Kant's primary concern was to show that morality, as the freedom to choose between right and wrong, is possible in a Newtonian world governed by material causes. To prove his case, he introduced the distinction between the empirical world, which is causally determined, and the noumenal world, which is not. As bodily creatures, we belong to the former sphere, but as rational agents, we inhabit the latter. Our "morally-practical reason" is free to make its own laws, and to act in accordance with them, without paying unnecessary attention to the demands of the body.

As morality requires freedom, and freedom can be attributed only to our practical reason, or will, it follows that the only way to act morally is to obey the commands of the will. This is what Kant called autonomy: "Autonomy of the will is the property that the will has of being a law to itself. [Morality] is the relation of actions to the autonomy of the will $[\ldots]$. That action which is compatible with the autonomy of the will is permitted; that which is not compatible is forbidden." 30

Kant believed that the demands of practical reason are the same on all rational beings. This provides us with a test for our moral principles. In order to act autonomously, we must act according to rules which could be autonomously chosen by any rational agent. The requirements of the moral law are, in other words, universal. 
Why should autonomy be respected?

Kant thought that we should celebrate our autonomy, because it is the only thing that can distinguish us from the rest of the world, and make us moral. Desires, attitudes, and emotions belong to the empirical realm, which can be encountered only as a determined sequence of causes and effects. In this prearranged world of phenomena, there is no freedom of choice, hence no responsibility for one's actions, and hence no morality.

Autonomy of the will also makes human beings "equal to God" in the sense that, as rational beings, we, like God, can make our own laws. This is where Kant introduced the concept of dignity. In the empirical world, human beings are entities of little significance, and human feelings, desires, aspirations, and inclinations do not amount to much. In Kant's words, however: "man as a person, i.e., as the subject of a morally-practical reason, is exalted above all price. For as such a one (homo noumenon) he is not to be valued merely as a means to the ends of other people, or even to his own ends, but is to be prized as an end in himself. This is to say, he possesses a dignity (an absolute inner worth) whereby he exacts the respect of all other rational beings in the world, can measure himself against each member of his species and can esteem himself on a footing of equality with them." ${ }^{29}$

Autonomy, then, means rational self determination in accordance with universal moral laws. It should be respected, in oneself and in others, because it is the basis of our morality and dignity, and enables us to belong to the same moral community with God.

\section{How should autonomy be respected?}

Respect for freedom in the Lockean sense and respect for autonomy in the Kantian sense can, in theory, produce similar normative conclusions in our present context. It could be argued that universal reason, if interpreted correctly, would not oppose the use of cannabis, especially if there are good medical grounds for this. Then autonomy as conformity to the moral law would not require restrictions of freedom as the non-restriction of options.

But it can also be argued that the use of cannabis would not, in fact, be consistent with the demands of humanity and universal reason, as defined by Kant. The use of psychoactive substances confuses the mind and leads to addiction, and these are serious matters within the Kantian model, since both bafflement and chemical dependency are prone to hinder rational, self determined decision making. Reduction of suffering is, of course, a worthwhile goal, but it should not, according to Kant, be pursued at any cost. We should not, he argued, take our own lives in the face of suffering or sell our integral body parts to defeat poverty, because these actions would diminish our dignity as human beings. ${ }^{31}$ How, then, could we legitimately give away our presence of mind-the basis of our rationality-in order to avoid pain and anguish? These are, after all, only phenomena of the empirical world, while clarity of mind connects us with the rational realm.

Medical professionals who embrace the Kantian notion of autonomy should probably not prescribe cannabis to their patients. If rational decision making ought not to be hindered, and if the confusion and addiction related to the use of cannabinoids would have this effect, then it would be wrong to do so. Respect for autonomy in this sense seems to preclude the option of alleviating pain with psychoactive drugs.

\section{MORAL AND POLITICAL ARGUMENTS AGAINST PRESCRIBING CANNABIS}

There are three main moral and political lines of argument against allowing cannabis use and prescriptions. The first is an appeal to concrete harm, and can be formulated in terms of freedom and its legitimate restrictions. The second states that autonomy should be preferred to freedom, when these clash. The third is an appeal to values which cannot be expressed in terms of harm and individual autonomy. None of these arguments is conclusive in our present context.

\section{Medical cannabis does not inflict harm on others}

Within the liberal model, freedom can be legitimately restricted, if respect for it would inflict harm on innocent third parties. ${ }^{32}$ For those who want to allow the medical use of cannabis, but who remain sceptical regarding its recreational applications, this could provide a basis for making the required distinction. They can argue that even if the full legalisation of marijuana could have adverse effects on family relationships, workplace security, or traffic safety, these effects can be contained in the medical setting. This has, after all, been the case with opiates and other psychoactive drugs, which have been medically available in most countries for decades.

The liberal model may also work for those who want to grant competent adults the right to use cannabis, but who do not like to see children subjected to it. They can claim that children are not capable of making free choices, and cannot therefore adequately consent to the risks involved. Letting them use potentially harmful substances would equal inflicting harm on them. Claims like this would, within the liberal model, have to be validated by empirical evidence. In the case of cannabis prescriptions, the evidence for freedom already exists in the form of the relative harmlessness and subsequent acceptability of opiates and other psychoactive drugs. In the recreational context, those defending the current restrictions ought to be able to show what harm would be inflicted on innocent third parties by the legalisation of marijuana.

\section{A preference for autonomy does not support prohibitions}

Some theorists prefer the Kantian concept of autonomy to the Lockean notion of freedom, because respect for autonomy does not necessarily demand respect for choices we see as irrational, or immoral. Freedom as the non-restriction of options may require us to allow the use of cannabis, but a more prohibitive attitude can be justified by the prudential and moral good of the users themselves. They must be rescued from confusion and addiction, which can only undermine their rational autonomy and dignity as persons.

This paternalistic line of argument has its defenders, but it also has its theoretical weaknesses. ${ }^{33}$ If other people tell me what I should choose for my own good, then in what sense are we talking about my good, as opposed to other people's perceptions and attitudes? Questions like this should at least be carefully addressed in particular cases before freedom is restricted in the name of autonomy.

Bearing this in mind, it would not be easy to extend considerations of autonomy to the medical use of cannabis. Addiction is not an issue for terminal patients, and if they are already confused by pain or anxiety, there is no reason to restrict their freedom. For non-terminal patients who want to be cured, the case is even stronger. If they and their carers are convinced of the effectiveness of cannabis, then what could undermine their autonomy and dignity more than a ban on the medicine they want to use?

The established and accepted use of other psychoactive drugs further weakens the autonomy based ban on cannabinoids. Morphine is commonly prescribed to relieve pain despite its confusing and addictive effects. How could autonomy in the Kantian sense provide an argument against the use of cannabis, when morphine and other similar drugs are, at the same time, a part of standard medical practice? 


\section{Respect for symbolic values cannot support prohibitions}

The liberal assumption is that restrictions are not justified unless there is evidence of concrete harm on innocent third parties. Many critics of the model think, however, that this burden of proof is excessive and misplaced. They have argued that the harm produced by the use of marijuana is moral rather than physical, and indirect, inconspicuous and symbolic rather than direct, visible, and concrete. $^{34}$ Prudential precaution and a commitment to the values of the society demand us to prevent the use of substances which confuse the mind, corrupt the young, and challenge our perception of what is right and good.

Whatever the merits of arguments like this in the context of recreational drug use, they cannot be reasonably applied to the case of prescribing cannabis to alleviate pain and anxiety. The direct and concrete reduction of suffering provides, in almost any system of values, an excuse for causing some offence or creating a mild threat of unspecified future harm. I am also tempted to say that systems of value which do not recognise this excuse can be justly ignored in moral and legal discussions.

\section{WHAT ARE THE ANSWERS?}

My first question was, should I be free to use cannabis to alleviate my pain and anxiety? The answer, based on my individual freedom, is yes. Medical facts are too vague to overturn my informed choice, concrete harm is not inflicted on innocent third parties, and considerations of autonomy and symbolic harm cannot outweigh the suffering that can probably be removed by the drug.

My second question concerned the implications of my entitlement for medical professionals. These, too, are unambiguous. If prescribing cannabis is legally permitted, physicians should prescribe it to their patients whenever it is, in their best professional judgement, called for. If, on the other hand, the medical use of cannabis is prohibited, physicians should make it known to the political and legal authorities that the prohibition is unethical, and that it should be removed forthwith.

The case for the free sale and use of cannabis for recreational purposes, and the case for prescribing it to suffering patients, are slightly different. As people are allowed to buy and use many dangerous substances anyway, there are strong analogical grounds for permitting the sale and use of cannabis products. This is not, however, a sufficient argument for prescribing cannabis, as medical professionals are legitimately concerned about the wellbeing of their patients. On the other hand, the pain and anxiety experienced by the patients provide an additional reason for permitting cannabis prescriptions, although this consideration cannot be extended to non-medical contexts.

\section{REFERENCES}

1 Matsuda LA, Lolait SJ, Brownstein MJ, et al. Structure of a cannabinoid receptor and functional expression of the cloned cDNA. Nature 1990;346:561-4
2 Munro S, Thoms KL, abu-Shaar M. Molecular characterization of a peripheral receptor for cannabinoids. Nature 1993;365:61-5

3 Mechoulam R, Ben-Shabat S, Hanus L, et al. Identification of an endogenous 2-monoclyceride, present in canine gut, that binds to cannabinoid receptors. Biochem Pharmacol 1995;50:83-90.

4 Martin WJ, Loo CM, Basbaum Al. Cannabinoids are anti-allodynic in rats with persistent inflammation. Pain 1999;82:199-205.

5 Martin WJ. Basic mechanisms of cannabinoid-induced analgesia. IASP Newsletter 1999 Summer:3-6.

6 Kalso E. Cannabinoids for pain and nausea: Some evidence but is there any need? BMJ 2001;323:2-3.

7 Campbell FA, Tramèr MR, Carroll D, et al. Are cannabinoids an effective and safe treatment option in the management of pain? A qualitative systematic review. BMJ 2001;323:13-16.

8 British Medical Association. Therapeutic uses of cannabis. London: Taylor \& Francis, 1997.

9 Tramèr MR, Carroll D, Campbell FA, et al. Cannabinoids for control of chemotherapy induced nausea and vomiting: quantitative systematic review. BMJ 2001;323:16-21.

10 Meek C. Doctors want cannabis prescriptions allowed. BMA News Review 1994 February: 1-19.

11 US Dept of Justice, Drug Enforcement Agency. In the matter of marijuana rescheduling petition, Docket \#86-22, 6 September 1998.

12 Doblin R, Kleiman MAR. Marijuana as anti-emetic medicine: a survey of oncologists' experiences and attitudes. J Clin Oncol 1991;9:1275-80.

13 Kassirer JP. Federal foolishness and marijuana. N Engl J Med 1997:336:366-7.

14 Beauchamp TL, Childress JF. Principles of biomedical ethics, 5th edn. New York: Oxford University Press, 2001.

15 Ralph Seeley v State of Washington. No 63534-0. Supreme Court of the State of Washington, July 24, 1997.

16 Husak DN. Liberal neutrality, autonomy, and drug prohibitions. Philos Public Aff 2000;29:43-80.

17 Berlin I. Two concepts of liberty. In: Quinton A, ed. Political philosophy. Oxford: Oxford University Press, 1967:142-52.

18 Takala T. Concepts of liberty and the moral limits of patient autonomy. In: Thomasma DC, Novak D, Weisstub D, eds. Foundations of healthcare. Dordrecht and Boston: Kluwer Academic Publishers, (in press).

19 Feinberg J. Social philosophy. Englewood Cliffs, New Jersey: Prentice Hall, 1973.

20 Häyry M, Airaksinen T. Hard and soft offers as constraints. Philosophia 1988; 18:385-98

21 Locke J. Two treatises of government (1690) London and Melbourne: Dent, 1924.

22 Chadwick RF. Playing God. Cogito 1989;3:186-93.

23 Häyry M. Categorical objections to genetic engineering: A critique. In: Dyson A, Harris J, eds. Ethics and biotechnology. London and New York Routledge, 1994:202-15.

24 Mill JS. On liberty (1859). Reprinted in: Mill JS. On liberty and the subjection of women. Ware, Herffordshire: Wordsworth, 1996.

25 Takala T, Häyry M. Genetic ignorance, moral obligations and social duties. J Med Philos 2000;25:107-13.

26 Rhodes R. Genetic links, family ties, and social bonds: rights and responsibilities in the face of genetic knowledge. J Med Philos 1998;23:10-30.

27 Harris J, Keywood K. Ignorance, information and autonomy. Theor Med Bioeth 2001;22:415-36.

$28 \mathrm{O}^{\prime}$ Neill O. Autonomy and trust in bioethics. New York: Cambridge University Press, 2002.

29 Kant I. Metaphysische Anfangsgründe der Rechtslehre (1797). Translated by Ladd J, and reprinted in Kant I. Metaphysical Elements of Justice. 2nd edn. Indianapolis and Cambridge: Hackett Publishing Company, 1999.

30 Kant I. Grundlegung zur Metaphysik der Sitten (1785). Translated by Ellington JW, and reprinted in Kant I. Ethical Philosophy. 2nd edn. Indianapolis and Cambridge: Hackett Publishing Company, 1994

31 Kant I. Metaphysische Anfangsgründe der Tugendlehre (1797). Translated by Ellington JW, and reprinted in Kant I. Ethical Philosophy. 2nd edn. Indianapolis and Cambridge: Hackett Publishing Company, 1994

32 Feinberg J. Harm to others. New York and Oxford: Oxford University Press, 1984.

33 Feinberg J. Harm to self. New York and Oxford: Oxford University Press, 1986.

34 Feinberg J. Offense to others. New York and Oxford: Oxford University Press, 1985. 